\title{
EDITORIAL
}

\section{In This Issue: Raise the Gaze}

\author{
Kurt C. Stange, $M D, P b D$, Editor
}

Ann Fam Med 2014;12:398-399. doi: 10.1370/afm.1707.

$\mathrm{A}$ rticles in this issue subtly beseech us to move from ogling the ordinary to perceiving the possibilities at other levels of focus. They entreat us to raise our gaze from:

- the medical to the social determinants of health ${ }^{1}$

- the policies and particulars of case management programs, to their effects on people and populations ${ }^{2,3}$

- caring for disadvantaged, disenfranchised individuals, to helping people participate in the political process ${ }^{4}$

- designing portals to enable patients to access personal health records, to assessing how this technology can be implemented in small and medium sized practices $^{5}$

- referring to advising ${ }^{6}$

- rigor to relevance in research ${ }^{7,8}$

- bemoaning reductions in the contribution of family physicians to the child health workforce, to knowing some of the factors that underlie recent changes ${ }^{9}$

- lamenting that so many people die in the hospital, to understanding how family physicians can deftly take on different roles to help terminally ill patients spend their last days in familiar surroundings ${ }^{10}$

- depersonalized, inflexible, unsustainably expensive care in one health care system, to patient-centered, transparent, and affordable care in another system ${ }^{11}$

- literal to meaningful translation and communication ${ }^{12}$

- the personal turmoil of being the target of legal action, to the transcendent effects of helping another person ${ }^{13}$

Ian McWhinney observed that a uniquely important (and often unsupported and undervalued) facet of family medicine is "an acquaintance with the particulars."14 The articles in this issue incite the notion that personal knowledge is vital to the effectiveness of primary care. ${ }^{15}$ They also remind us that a unique and essential element of the generalist approach involves iteration ${ }^{16}$ between the particulars of the person in front of us, the social environment that shapes their possibilities for health, and the systems that influence their health care. At whatever level we work in health care, the ability to periodically raise and lower the gaze increases the possibilities for doing good, and provides the opportunity to minimize unintended consequences. ${ }^{17,18}$ This iterative raising and lowering the level of focus is the essence of the generalist approach. ${ }^{16}$ It is the subtle need and the abundant opportunity to improve the station of vulnerable people, communities, and systems.

\section{Forthcoming}

A movement is trying to happen in the United States to cultivate a commons for integrated, personalized, and sustainable health care that releases resources upstream toward the social and environmental determinants of health. Some of these uprisings cancel each other out, as opposing individual interests undermine change. But others are uniting to trigger tides of transformation toward health care that is integrated, personalized, and relationship-centered.

Into this foment, 8 family medicine organizations based in the United States have come together to inaugurate Family Medicine for America's Health "to revisit the role of family medicine in view of these changes and to position family medicine with new strategic and communication plans to create better health, better health care and lower cost for patients and communities (the Triple Aim)."19 This new collaboration builds on the decade-old work of 7 family medicine organizations in the Future of Family Medicine project, which instigated a series of efforts to "renew the specialty to meet the needs of people and society."${ }^{120}$

This new plan is a small ripple, a starting point for iterative interactions in the big pond of US health care and other societal movements that demand a healthy populace. But the family medicine organizations are "all in," and are committing a substantial portion of their resources to continuing to evolve a plan to improve family physicians' ability to contribute to the emerging movement. There will be dampening forces. But also the possibility that the ripples of these organizations' collective efforts will resonate with enough other forces and efforts to create a sea change towards a more rational, sustainable, and effective system.

An article describing the initial steps of Family Medicine for America's Health will be published online as an Annals supplement on October 23, 2014.

We welcome your reflections at http://www.AnnFam Med.org. 


\section{References}

1. Trachtenberg AJ, Dik N, Chateau D, Katz A. Inequities in ambulatory care and the relationship between socioeconomic status and respiratory hospitalizations: a population-based study of a Canadian city. Ann Fam Med. 2014;12(5):402-407.

2. Phillips RL, Han M, Petterson SM, Makaroff L, Liaw WR. Cost, utilization, and quality of care: an evaluation of Illinois' Medicaid primary care case management program. Ann Fam Med. 2014;12(5):408-417.

3. Khanassov V, Vedel I, Pluye P. Barriers to implementation of case management for patients with dementia: a systematic mixed studies review. Ann Fam Med. 2014;12(5):456-465.

4. Liggett A, Sharma M, Nakamura Y, Villar R, Selwyn P. Results of a voter registration project at 2 family medicine residency clinics in the Bronx, New York. Ann Fam Med. 2014;12(5):466-469.

5. Krist $\mathrm{AH}$, Woolf $\mathrm{SH}$, Bello $\mathrm{GA}$, et al. Engaging primary care patients to use a patient-centered personal health record. Ann Fam Med. 2014;12:418-426.

6. van der Zwaard BC, van der Horst HE, Knol DL, Vanwanseele B, Elders PJM. Treatment of forefoot problems in older people: a randomized clinical trial comparing podiatric treatment with standardized shoe advice. Ann Fam Med. 2014;12(5):432-440.

7. Peek CJ, Glasgow RE, Stange KC, Klesges LM, Purcell EP, Kessler RS. The 5 R's: an emerging bold standard for conducting relevant research in a changing world. Ann Fam Med. 2014;12(5):447-455.

8. Ewigman B. Could 5R research help achieve the Triple Aim? Ann Fam Med. 2014;12(5):399-401.

9. Makaroff L, Xierali IM, Petterson SM, Shipman SA, Puffer JC, Bazemore AW. Factors influencing family physicians' contribution to the child health care workforce. Ann Fam Med. 2014;12(5):427-431.
10. Reyniers T, Houttekier D, Pasman HR, Vander Stichele R, Cohen J, Deliens L. The family physician's perceived role in preventing and guiding hospital admissions at the end of life: a focus group study. Ann Fam Med. 2014;12(5):441-446.

11. Rao SR. A tale of 2 countries: the cost of my mother's cardiac care in the United States and India. Ann Fam Med. 2014;12(5):470-472.

12. Brown BP. Interpreting medicine: lessons from a spanish-language clinic. Ann Fam Med. 2014;12(5):473-474.

13. Kannai R. It finally happened to me. Ann Fam Med. 2014;12(5): 475-477.

14. McWhinney IR. 'An acquaintance with particulars...'. Fam. Med. 1989;21(4):296-298.

15. Stange KC, Miller WL, McWhinney I. Developing the knowledge base of family practice. Fam Med. 2001;33(4):286-297.

16. Stange KC. The generalist approach. Ann Fam Med. 2009;7(3): 198-203.

17. Stange KC. Refocusing knowledge generation, application and education: raising our gaze to promote health across boundaries. Am J Prev Med. 2011;41(4)(Suppl 3):S164-S169.

18. Aungst $H$, Ruhe M, Stange KS; PHAB Staff and Writing Committee. Boundary spanning and health: invitation to a learning community. Lond J Prim Care. 2012;4(2):109-115.

19. Phillips RL, Pugno PA, Saultz JW, et al; Family Medicine for America's Health Writing Group. Health is primary: family medicine for America's health. Ann Fam Med. In press.

20. Martin JC, Avant RF, Bowman MA, et al. The future of family medicine: a collaborative project of the family medicine community. Ann Fam Med. 2004;2(Suppl 1):S3-S32.

\title{
EDITORIAL
}

\section{Could 5R Research Help Achieve the Triple Aim?}

\author{
Bernard Ewigman, MD
}

Department of Family Medicine, The University of Chicago/NorthShore University HealthSystem, Chicago, Illinois

Ann Fam Med 2014;12:399-401. doi: 10.1370/afm.1708.

I $\mathrm{s}$ it possible to meet the standards of the bold research model proposed by Peek et al in this issue of Annals of Family Medicine? ${ }^{1}$ And if it is possible, would it be worth the effort and investment required?

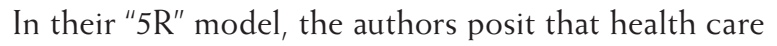
delivery research could not only be relevant, applied, and implemented, it could also be participatory (all stakeholders), grant funded (rapidly), published

Conflicts of interest: author reports none.

\section{CORRESPONDING AUTHOR}

Bernard G. Ewigman

Department of Family Medicine

The University of Chicago/NorthShore University HealthSystem Chicago, Illinois

bewigman@uchicago.edu (quickly and retrievable), continued in the operational workflows of the practice setting (if successful), and replicable in other practice settings.

It is tempting to dismiss the expectations of this model as idealistic, unrealistic, and overly ambitious. Training a career researcher in any one of the methods outlined, launching a single junior faculty in a successful focused research career, or building a sustainable organizational research enterprise with a defined research agenda takes years of effort and investment. ${ }^{2,3}$ Are these authors proposing a bold standard, or an impossible one for all but the rare case? Or is this a brilliant, innovative, and achievable synthesis of many research methods and traditions that is not only feasible, but worthwhile-even imperative-to pursue?

The potential value of this model is too compelling to dismiss. Theoretically, the human beings leading 